\title{
The Crime of Unbalanced Cheque
}

\author{
Dr. Khalid Mohammed Ajaj \\ Faculty of Law/ Cihan University/ Sulmaniyha
}

\begin{abstract}
The cheque has a significance importance as it is used in all fields of life and is also used an important source of money. For all of this and for other reasons, the criminal legislation had to interfere to make it legal when dealing with the use of cheques according to legal contexts. The violation of such legal contexts will result into interrogation and punishment. According to such law, it is considered a crime when giving a cheque without any balance or giving a cheque that has insufficient account. The current paper aims at showing the features of giving a cheque without a balance and clarifying how Iraqi law deals with such kinds of crimes. It also urges the Iraqi legislator to emphasis the punishment of giving a cheque without a balance.
\end{abstract}

\section{INTRODUCTION}

Giving cheques without a balance is still a problem that the society is engaged with because of its dangerous consequences socially and economically. When someone makes a cheque to another one, the one who gets the cheque should be entirely aware of the balance and tomake sure that the cheque in due should be financially secured. However, some people abused the cheques when they used them as a means of taking the amounts of money of other people. This is done through making cheques without any balance and giving them to people and such action resulted into the fact that many people lost confidence in using them as a means of commitment (the cheques). Thus, to a certain extent, the use of the cheque as an economical tool starts to lose its validity and significance. Hence, the legal contexts concerned with preventing or decreasing the abuse of cheques are considered inefficient. The current paper is entirely concerned with explaining how such crime is committed and what the punishment will be according to the Iraqi Laws.

\section{WHAT CHEQUEARE}

The cheque is considered one of the well-known commercial papers practically due to its importance in various kinds of treatments. It is mainly characterized with the facthat it decreases the need of the use of the cash and, as a result, delimits the amount of the used cash. Moreover, the cheque doesn't force the drawer (the owner of the cheques)to keep the money and this leads to decreasing the risks of the loss or the robbery of the money. Additionally, the cheque is considered an effective means of showing commitment where the bank can easily prove that has been paid on due.In fact, the Iraqi Laws of Punishment did not refer to the definition of the cheque. However, the article 459 included some references to the aforementioned issue *. The jurists differed in the issue of inserting the definition of the cheque; those who agree and those who do not. Those who agree justify it by saying that it will provide the protection to those who use it (Mohammed, 1986: 6). Those who disagree justify it by saying that inserting the definition will lead to delimit the data which does not get along with the practical reality as it confines the users of the cheques. This lead to disagreements concerning the influence of the data and the cheque (Sadiq, 1985:6). In fact, there is a tendency towards the latter opinion as it is illogical putting a definition of cheque within the framework of law according to the changes that the society may witness as far as the economical, social and political aspects are concerned. As long as the regulations of cheques are stated in the law, it is subject to the legal understanding (Abdulaziz, 1997: 53).

\section{DISTINGUISHING CHEQUES FROM OTHER COMMERCIAL FORMS}

The commercial papers can be divided into cheques, drafts, bonds and others (Jamilalddin, 1986:7). The main difference between the cheque and other kinds of commercial formal papers is that it is considered a tool of commitment because it is valid once it is presented to the bank. It is also considered a money receipt that the one who has it can use it whenever he/she likes. The other forms of the commercial papers are tools of credits; they are bonds which prove the debt for a specific time that may be extended or delayed according to the agreement which governs it (ibid). In general the cheque is distinguished from the draft in many ways but it also similar to it in some respects. In essence, the cheque is similar to the draft in that there are three parties: the drawer, the drawee and the beneficiate. It also resembles it in that both have authentic relation between the drawer and the drawee and that is the crediting balance (Eid, 1975: 3). On the other hand, the cheque differs from the draft in the following ways: 
1. The cheque should contain balance while the draft doesn't necessarily contain.

2. The cheque is a commitment tool whereas the draft is a postponed credit.

3. The draft could be presented to the drawee to be accepted before its due while this is not a condition when it comes to the use of the cheque.

4. The cheque doesn't necessarily contain the name of the beneficiate but the draft should contain the name of the person to whom the money to be paid.

The cheque is also different from the promissory note in that it may have two or more parties while the promissory note has two parties only. If the cheque is violated, there would be criminal punishment while the promissory note if violated results into civil responsibility (AL-Qaluby, 1976: 398-409).

\section{THE CRIME OF THE UNBALANCED CHEQUE}

The crime of a false or unbalanced cheque is considered a crime when three elements happen: the materialistic element and the place of a cheque without an account and the moral element. The moral elementrequires verification that the material element of the drawer after the issuance of the check and transferring the possession and give to the beneficiary or his agent put any trading intent to transfer full possession of the beneficiary to give up ownership of the drawer once and for all.It should be noted that the material element of the offense of giving a check without balance of specific images specified in Article (459) of the Penal Code, as follows:

First, giving a check is not perfect against the existing fulfillment inalienable:

Crime here is achieved by the liberalization of the drawer of the check and he knows that there is no return for a complete fulfillment of his own account then issuing an order to the beneficiary so the drawer shall be responsible for the crime of giving a check without balance. The other important issue is retrieving the cheque before getting the money. And this is done through getting the entire account by the drawer at the drawee balance recovery. Or the drawer recovers some of the account so that what remains of it is not enough to repay the amount of the check and doesn't spare the drawer of the responsibility, whatever the motive for this recovery. In all cases, preventingcashing the check is the significant issue that is to be considered. This is done through the fact that the drawer issues an order to the drawee not to exchange, although the check satisfies the conditions and balance enough and capable of pulling the time of release. The exception to this is not considered a crime according to article 163 of the Trade Act if it's after the payment due to the loss of the check, being robbed or judging its holder to insolvency.

In general, Iraqi legislature has considered that the crime of delivering or signing the cheque is a crime if it meets the aforementioned elements. It has equated the endorsement and delivery in terms of punishment if the drawer endorses or delivers a check to someone else and he knows that is doesn't fulfillthe amount in due (Shoyash, 2009: 357). The second element is the element crime of the cheque. In the widest sense, the cheque is known as an order issued by the owner, who is called the drawer, into a bank requesting to pay a sum of money to the order of a person appointed in this instrument as soon briefed on it. It also known that it is a structured shape in accordance with the stipulated conditions stated by the text of the law under which the terms of the drawer orders people to pay a certain amount to a third person, so the check is different from other commercial papers. As the check is a tool of commitment, it is payable once submitted. As for the bills and bonds, they are regarded as a credit instrument which are not payable until after the expiration of a period of time has been lengthened and shortened by law or agreement (ibid:).

The third element of the unbalanced cheque is the moral element. There is no doubt that giving a check without balance is a crime of deliberate offenses that requires the availability of general criminal intention (knowing and the will). The drawer must know when issuing a check that it does not have enoughbalance. This cannot be achieved if the drawer is believed that it covers the value of the check and proves insufficient. So the drawer should make sure the before issuing the check (Galani, 2004).But the will is intended to the direction of the will of the drawer to issuing the check and this means to have a balance which exists and is intended to push or pull part of the balance after giving the check amount to decrease the balance. In other cases it may mean that the drawer issues an order to the drawee not to cash the check in the cases stipulated by law. It is clear from the text of Article (459) of the Penal Code that the intent requirement for the crime of giving a check without balance is the general intent. It is worth mentioning that some jurists are inclined to the necessity of the occurrence of the private intent in which the intention of the drawer is directed to harm the beneficiate (Attai, 1956: 267). The reason of the existence of this opinion is the phrase "ill-intention" which the legislator used as the explicit interpretation of the text shows that it is necessary for the private intent to be available. However, the probable opinion is the existence of the general criminal intent in the crime of giving a cheque without a balance because the main priority of the legislator is protecting the value granted by the cheque (ibid). 


\section{THE PUNISHMENT OF THE UNBALANCED CHEQUE}

The crime of giving a cheque without a balance is considered a felony which is punished by imprisoning and paying a fine no more than three hundred dinars. Since this punishment is very significant as it deals with such crimes and since punishment is considered a means of social and economical reformation, reconsideration of this kind of punishment took place. Such reconsideration is directed towards increasing the amount of fine in addition to making it more vital. It is now a legal item that the punishment of such crimes is as in the following:Anyone who commits such crime shall be punished by imprisonment for not less than three years and a fine equivalent to five times the amount of the instrument that no fewer than three thousand dinars who gave the instrument in bad faith and he knows that he is not fulfilling enough. In other cases, it is considered a crime if the filled information is done improperly that prevents the drawer from cashing. In general, if the cheque doesn't fulfil the amount in due, it is considered a crime. Any violation of giving a cheque is considered a crime that has a specific punishment as the law stated.

\section{CONCLUSION}

The cheque is a form of the commercial papers, which replaces the cash deals. On such basis, laws are initiated to regard the act of giving unbalanced check as a crime punished by law according to the Penal Code. Such crime shall be punished in accordance with the penal law as soon as giving the drawer of the check to the beneficiary knowing that it is is not against the fulfillment retractable, or withdrawing after giving each other hand or in part, so that it does not meet its value. The crime of unbalanced cheque is considered a crime of fraud which is punished according to the article (459)which states that the convict is to be imprisoned and to be fined (not more than three hundreds). In fact the panel code protects the uses of the cheque aslong as it is valid and does not violate the laws.

\section{BIBLIOGRAPHY}

[1] Abdul Aziz, M., A. (1997). The Crime of Giving an unbalanced Cheque: A Comparative Study. Cairo: University of Ein Shams.

[2] AL-Qaluby, S.(1976). The Commercial Law. Cairo:Dar AL-Nahatha AL-Arabia.

[3] Attai, Mohammed. (1956). The Crime of Issuing Cheques without Balance in the Egyptian Legislation. Cairo: Dar AL-Nahatha AL-Arabia.

[4] Eid, Edaward.(1975). The Criminal Protection of Cheque in the Arab Legislation. Cairo:Dar AL-Nahatha AL-Arabia.

[5] Galani, F. (2004). The Crimes of Money. Beirut: The Institution of AL-Resala for Printing and Publication.

[6] Jamilalddin, Ali.(1986). Commercial Laws and Works of Banks. Cairo: Dar AL-Nahatha AL-Arabia.

[7] Mohammed, S. Salah. (1986). The Criminal Protection of Cheque. Cairo: Police Academy.

[8] Sadiq, H.(1985). The Crimes of Cheques. AL-Askandirai: AL-Maraf Facility.

[9] Shoyash, Abid, M.(2009). Explaining Laws of Punishment. Cairo:Dar AL-Nahatha AL-Arabia. 